\title{
Green Revolution: Impact on Gender
}

\author{
I. Sobha \\ Department of Women's Studies, Sri Padmavati Mahila Visvavidyalayam, Tirupati 517 502, \\ Andhra Pradesh, India \\ E-mail: sobhareddyi@msn.com
}

KEYWORDS Displacement. Environment. Green revolution. Poverty. Strategy

\begin{abstract}
Women of third world countries, or in the developing countries, play a major role in managing natural resources. Women have always had a close relationship with the trees and the forests and traditionally they have gathered products, which have provided them with the basic three 'Fs' of fuel, food and fodder and for a variety of other uses. While men consider the forest more in terms of commercial possibilities, women see it as a source of basic domestic need. They have a profound knowledge of the plants, animals and ecological processes around them. Their role in agriculture and animal husbandry as well as in the household activities makes them the daily managers of the living environment. Third world peasants, who were mainly women, for over centuries have innovated in agriculture and the methods they used have been lasting and sustainable, this knowledge which was acquired for over centuries began to be eroded and erased with western model of green revolution. Globally, the major threat to the environment, in terms of promoting agricultural exports, has been through the replacement of traditional food crops by hybrid cash crops. Degradation of land, pollution through pesticides and fertilizers and loss of biodiversity has been some of the more disturbing environmental impacts. Because of the unchecked pollution women are the worst affected, they have also caused health problems among children and men. The present paper examines the impact of such changes on women with the help of a few research studies.
\end{abstract}

\section{INTRODUCTION}

Women, particularly those living in the areas of Third World Countries, or in the developing countries, play a major role in managing natural resources - soil, water, forests and energy. Women have always had a close relationship with the trees and the forests and traditionally they have gathered products, which have provided them with the basic three 'Fs' of Fuel, Food and Fodder and for a variety of other uses, where as men consider the forest more in terms of commercial possibilities, women see it as a source of basic domestic need. They have a profound knowledge of the plants, animals and ecological processes around them. Their role in agriculture and animal husbandry as well as in the household activities makes them the daily managers of the living environment (Annabel, 1991; Dankelman, 2004)

\section{FOOD PRODUCTION - DISPLACEMENT OF WOMEN}

Third world peasants, for over centuries, have innovated in agriculture and the methods they used have been lasting and sustainable, these peasants were mainly women. The knowledge of agriculture which was acquired for over centuries began to be eroded and erased with the introduction of western model of green revolution.

The shift from nature's economy and survival economy to market economy resulted in the utility of hybrid seeds, chemical fertilizers and pesticides. Large scale irrigation and mechanization of agriculture and the new breed of agricultural experts have all been responsible for the displacement of women and peasants who were traditional agricultural experts. This has resulted in the removal of land, water and forests from women's control and management which resulted in women loosing their productivity. Added to this the ecological destruction of soil, water and vegetation systems have impaired the nature's productivity and renewability.

While gender subordination and patriarchy are the oldest of oppressions, they have taken on new forms through the project of development. Women, tribal and peasant societies embedded in nature are considered unproductive, not because they produce less goods and services for needs, but it is assumed that 'production' takes place only when new technologies are introduced for commodity production, even when such technologies are responsible for destruction of life. The destruction of ecologically sound traditional technologies, often created and used by women, is generally believed to be responsible for the 
'feminisation' of poverty in societies which had to bear the brunt of such resource destruction (Shiva, 1992)

These natural resources are the basis of nature's economy and women's survival economy. The impoverishment of women and marginalisation of people in an unprecedented manner lies in the fact that resources which supported their survival were absorbed into the market economy while they themselves were excluded and displaced by it. While it draws men away from basic food production and increases women's work load for producing subsistence and forces them to walk longer distances for water, fodder and fuel. Women's role shifts from the soil builders and primary producers of farm products to the economic category of subsidiary wage earners on agricultural farm. Women's marginalization has resulted in losing their control over land as a means of production, this is evident from the fact that the number of the female cultivators has dropped, it is further aggravated by the differential wages in agricultural labour (Mies, 1987)

\section{GREEN REVOLUTION}

The nature of women's work in agriculture traditionally has been to in integrate forestry and animal husbandry with farming. Agriculture modelled on nature and based on women's participation with nature has been self-reproducing and sustainable because the internally recycled resources provide the necessary inputs for seeds, soil moisture, soil nutrients and pest control.

The paradigm of masculinity in food production has come to us in many shades and labels, such as 'green revolution', 'scientific agriculture' etc., They involve the disruption of the essential links between forestry, animal husbandry and agriculture, the basis of the agriculture which was provided by women through carrying green manure and fodder to farms and carrying compost and organic matter to fields. This has been destroyed by replacing renewable inputs from the farm by non-renewable inputs from factories and in turn is displacing women from work, who were providing sustainable inputs. Farming as a process of nurturing the earth to maintain her capacity to provide food has changed with a masculinist shift in looking at farming as a process of generating profits.
Ecological destruction is one inevitable result of this commercial outlook and economic deprivation is the other because production for profits instead of needs, results in the exclusion of larger numbers of women and peasants from food production and their entitlement to food. The patriarchal model of development which looks at sales and profits as indicators of wellbeing and this is intimately related to the fact that large number of the poor in the Third World are victims of hunger and famine today (Mies and Shiva,1993)

\section{IMPACT OF GREEN REVOLUTION}

Fifty seven years after independence, persistent droughts, starvation deaths, suicides by farmers, half of our children chronically malnourished, a majority of our women are anaemic and every third village is suffering from lack of drinking water.

What is particularly disgraceful is that these are not natural calamities but are policy engendered and man made disasters. Globally, the major threat to the environment, in terms of promoting agricultural exports, has been through the replacement of traditional food crops by hybrid cash crops. Degradation of land, pollution through pesticides and fertilizers and loss of biodiversity has been some of the more disturbing environmental impacts. Through our cultivated fields, the poison, through pesticides and fertilizers, used indiscriminately to lure the land into producing more has percolated into our food chain and is present everywhere in milk products, vegetables, fish, grains, meat, groundwater even in breast milk.

\section{POOR WOMAN'S FUEL}

Men might be cooking and washing on television but not in the real world, these are still women's jobs. The lower you go down the economy ladder, fewer men are doing these household activities. In this economy ladder, after you go down a couple of rungs, there are no flashy microwave ovens, refrigerators and washing machines. The familiar red LPG cylinders also disappear some where around the middle.

A woman at this level, does not matter if she is 80 or 8 , pregnant or sick, has to ensure that her family has food to eat and water to drink, feed the animals the family has and if the husband is out 
looking for a job in a town, has to plough the fields. Women collect fuel wood, fetch water and care for the live stock and hence, they are more inevitably bound to natural resources than men.

When firewood is scarce, studies show that the rural people switch from using logs to little twigs and branches, and when even those are not available they move to crop residues, cow dung and even dry leaves. The use of biomass has a negative impact on the health of household members, especially when it is burned in doors without either a proper hearth or a chimney to draw the smoke out side. One of the reasons biomass energy has received so little attention in national energy planning is that it is a women's fuel. In other words, if men were the primary collectors of firewood, something would have been done about it long ago.

It is not surprising that they pay a greater price when environmental degradation takes place. Fuel wood collection is often referred to as a cause of deforestation. However as women mostly collect dead wood, which is easier to cut, their work does not damage the trees. Defore-station, water scarcity, soil degradation, exposure to agriculture and industrial chemicals and organic pollutants, they all affect women's work load, nutrition and health. For example, deforestation makes it more difficult to collect fuel wood. When women travel further and take more time to do these activities, girls become the first casualties. They are usually taken out of school to assist their mothers.

Environmental risks at home may have a disproportionate impact on women = so women's health because of women's different susceptibilities to the toxic effects of various chemicals. In fact, of the 3 million annual air pollution deaths, 2.8 million are from indoor air pollution. The figure is 2.2 million people for developing countries and the biggest at risk are rural women who spend hours in front of smoky chulhas. Nearly one-half of the total energy consumed in the country comes from non-commercial sources such as cow dung and vegetable waste (Gobar Times Poster, 2004).

\section{Poverty has a Woman's Face}

There is a curious phenomenon happening in Indian villages. As the local environment is fast degrading, and weakened agricultural soils are breaking down under tremendous stress, the men are leaving their homes for towns to earn more money. What happens to the women left behind? Divorce rates are high among emigrants, and the wives are usually deserted. Then there are added problems. Female headed households are generally poorer than male-headed households. This is a worldwide phenomenon and $70 \%$ of the world's poor are women.

According Swaminathan (2004), women are the sole or chief bread winners in 25 per cent of poverty stricken families. WHO estimate says that the energy used to carry water may consume one-third of a woman's daily calorie intake. A study from the plains of Western UP, an agriculturally prosperous area, shows that even pregnant women there had a 14-16 hour working day.

Women are more exposed to the hazards of polluted water than men. They are not only the primary carriers of water, but they wash clothes and utensils too, mostly with polluted water. Moreover, since childcare is primarily the woman's responsibility, when children get infected, women are more likely to catch the infection than men. Toxic chemicals and pesticides in air, water and earth are responsible for a variety of women's health risks. They enter body tissues and breast milk, through which they are passed on to infants.

\section{THE EFFECTS OF ENVIRONMENTAL DEGRADATION ON WOMEN}

A few research studies which have been mentioned highlight the impact of pesticides on people more particularly on women, who in fact are assigned these hazardous tasks. Instances of illegal land fills in urban areas have also affected the women in the form of their breast milk getting poisoned. Using of biomass has affected the women and the girl children as they are the one involved in cooking

1. Women exposed to pesticides such as DDT have hypothyroidism - a situation in which the thyroid gland is unable to, produce requisite processes. This leads to problems such as weight gain, lack of energy and falling hair.

A group researchers studied exposure to pesticides in 123 women who had come to the thyroid clinic of the hospital during 199798. The women who had a lower thyroid function had higher level of pesticide residues in their blood sample. However none of the women above the age of 50 years were found to have lower thyroid activity. According to the researchers, the older 
women might have lost the accumulated pesticides during the process of lactation and menstruation (Sawai Man Singh Medical College and Hospital in Jaipur, 2002).

2. Pesticide exposure can lead a Leukaemia in children. This has been proved by studies conducted by Sachadeva and Dutta (2002) Department of Paediatrics at Lady Harding Medical College, New Delhi who stated that, Pesticides cause biological changes in the body that enable cancer cells to multiply, rise in the incidences of brain cancer and acute lymphocyte Leukaemia are commonly found among children. High exposure to toxic compounds like pesticides (specially organophosphates) have long been recognised to cause nerve damage; called the nerve gas syndrome.

3. Pesticides also can cause Parkinson's disease.Scientists from the U S based Emroy University School of Medicine have found that several commonly used pesticides are toxic to the mitochondria - the energy supplying element of cell in all living beings. As a result of toxity, the mitochondria are unable to produce a key enzyme called "Complex I." It results in genetic damage that can lead to maladies such as the Parkinson's disease, which is one of the most fatal neuro-degenerative disorders that afflict humans (Emroy University School of Medicine, 2004).

4. Even the womb is no protection against pesticides. They found a strong link between prenatal exposure to chloropyrifos and low birth weight and smaller head size of infants. Several studies have correlated the smaller size of the head with lower intelligence quotient (IQ) and poor cognitive functioning (Columbia University, 2003).

\section{RULE OUT THE MENACE}

A ban imposed by the US Environmental Protection Agency (EPA) on two household insecticides, has significantly reduced the number of under weight babies born in localities where the chemicals had been widely used. Researchers from the US based Columbia University have found that infant birth weights and birth lengths in upper Manhattan area improved immediately after the pesticides chloropyrifos and diazinon were banned in 2000. During their study the researchers estimated pesticide levels in the blood of pregnant women. The results showed that the infants of pregnant women exposed to the highest amount of the pesticides were on an average 6.6 ounces lighter than kids of women exposed to lower doses. The findings are alarming, as low birth weight means a higher rate of health and developmental problems (Columbia University, 2002).

In the wake of such studies, countries like the UK have planned to phase out the pesticide. However, developing countries like India continue to use them on a large scale.

5. Pregnant women and foetus can be affected indirectly by pesticides such as polychlorinated biphenyls( $\mathrm{PCB})$, people bring pesticides used in farms and gardens and expose them to pregnant women. The study showed that children between 0-9 years whose parents had occupational exposure to pesticides developed acute lymphoblast anaemia (ALL) during early childhood. India still has one of the highest concentrations of DDT in breast milk in the world. DDT is known to cause severe nerve disorders in children (Lal and Bahl,2002).

6. Emissions of illegal landfills poison breast milk. After finding high levels of dioxin related compounds in breast milk of women living near landfills, a Vadodara based nongovernmental organisation, Paryavaran Suraksha Samithi (PSS) intended to file public interest litigation (PIL) against the Gujarat pollution control Board and the Vadodara Municipal Corporation. The PSS researchers compared breast milk samples from India with those from Cambodia and the Philippines. All the samples were found to contain the three toxic substances in varying degrees. The levels found are high enough to cause neurological damage (Rajnish Tiwari,2004).

7. A study by Kabra, a physician at the Indian Institute of Health Management Research in Jaipur, found that pesticide residues in food are responsible for deformed babies. An estimated 8000 babies are born with mental defects each year in Rajasthan (cited from Lal and Bahl, 2002).

8. Women and girl children who cook with the help of biomass are four times more likely to suffer from chronic obstructive pulmo- 
nary disease, such as chronic bronchitis, lung cancer, asthma, tuberculosis and low birth weight.

Women all over the world are more involved in environmental activities and are the most affected by degradation and pollution. Women are known to be better ecological managers than men. Even then they are kept out of environmental policies at the local, national and global levels.

Gandhiji was once asked, When we plan for our country, what should we remember most? Think of the last man, he replied. Experience has taught us, however, that the last man is invariably a woman. No other group is more affected by environmental destruction than poor village women. Every dawn brings with it a long march in search of fuel, fodder and water. It does not matter if the women are old, young or pregnant. As ecological conditions worsen, the long march becomes even longer and more tire some (Agarwal, 2004),

\section{BEST AMONG THE WORST}

World Health Organisation (WHO, 2002) identified top ten health risk factors. The latest World Health Report of the WHO states, of the 10 avoidable risk factors, malnutrition, unsafe sex, smoking and poor sanitation, account for 40 percent of global deaths each year. It also says that cheap remedies exist for many ailments and governments of all countries can do more to prevent unnecessary and premature deaths. It concludes that such counter measures could extend average life expectancy by five to ten years.

The risks are in sharp contrast between "Haves and have-nots". The poor people typically die because of lack of food and clean water, the rich die due to diseases of over indulgence. The reasons for these risks may be obvious but are shocking, of the 10 risk factors, the five that dominate in poor countries are, abnormally low body weight, unsafe sex, iron deficiency, unsafe water and exposure to indoor smoke from solid fuels. The smoke causes pneumonia in children and lung disease in woman. In richer countries, the five key killers identified are tobacco smoking, alcohol drinking, high blood pressure, high blood cholesterol and obesity.

\section{CONCLUSION}

Majority of women in sustenance economies, indulging in producing and reproducing wealth in partnership with nature, have been experts in their own right of a holistic and ecological knowledge of nature's processes. But these alternative modes of knowing are not recognised by the reductionist paradigm, though they are oriented to social benefits and sustenance needs, because it fails to perceive the inter connected-ness of nature, or the connection of women's lives, work and knowledge with the creation of wealth.

Due to the triple roles played by a woman as a home manager, economic provider and reproducer, has resulted in generating health problems and hazards in a number of categories. Over all health status has deteriorated in girl children and women compared to the other sex.

Here, again we are reminded of Mahatma Gandhiji's words that "Nature has enough to satisfy every one's need but not everyone's greed".

Owing to the greediness of the people in the name of development and patriarchal domination the quality of life has deteriorated among women who are considered as weaker sex.

\section{STRATEGIES FOR COMBATING ENVIRONMENTAL DEGRADATION AND ITS IMPACT ON WOMEN}

The fundamental cause of poverty in India arises out of the scarcity of biomass resources to meet daily basic needs like food, fuel, fodder, manure, building materials and artisanal raw materials, almost all of which are biomass based.

Environmental degradation makes it increasingly difficult for women to cope and they are hit first and hardest. Women are the most highly motivated group to mobilize for the promotion of sustainable use of natural resources. It is however, important for them to be helped to gain some control of the resources they are using and for their knowledge and expertise to be taken seriously.

1. Gender awareness should be there in all development activities particularly those aimed at introducing sustainable use of natural resources and finding solutions for environmental problems. This would mean, concern should be shown for gender differences in interest, motivation and perception of benefits, based on different tasks, responsibilities and access to resources.

2. women's organisations are generally consi- 
dered to have an important role in supporting women's participation, streng-thening decision-making in development policy, in order to ensure long-term sustainability of development activities

3. An important aspect in gender policy is involvement of local women experts and staff in the team of workers in developmental projects on an equal basis with men. This will not only facilitate working of women on the projects, but also underlines the fact that women are taken seriously and generally promote their participation. The modernization of agriculture, with mechanization, extensive irrigation and the introduction of hybrid crop species has marginalized women's traditional knowledge and experience in the use and management of natural resources. Development initiatives rarely take people's knowledge into account and certainly not women's expertise in such areas as soil conditions, seeds, crop varieties, and appropriate agricultural methods. Equally overlooked is women's expertise in water and fuel

4. The key objective of rural development programmes must be to restore ecological balance and increase biomass production on a sustainable and equitable basis. Hence, rural development programmes have to become ecosystem - specific.

5. The reality is that a heavy workload on the mother means the daughter cannot get an education even when access to a school is easy. Revamping the school system is needed so that it gives sometime off for girls to assist their mothers, especially during the months when the mother's work burden is high. The school calendar should, therefore, be flexible and in tune with the work calendar of the local agro ecosystem.

6. Women's right to own and inherit land should be enforced; individual and communal security of land tenure should be guaranteed, they should have access to credit, agricultural extension, resource management services, and they should be included in decisions about the services, organisation and content.

7. In the guise of technological development for sustainable development, environmental damage is being caused. The national environmental management policy has to be environment friendly and development oriented rather than being merely development - oriented. It is the need of the day that we must maintain, protect and preserve the environment not only for ourselves but also for future generations and survival of humankind at large.

Women in the third world play a major role in managing natural resources. They are also the first and worst hit by the mismanagement of environment, inspite of this they are neither consulted nor taken into account by development policy makers. Under these circumferences women must be taught to organise themselves to meet environmental challenges.

Good ecology is also good economics in the long term. Economists have to redefine poverty not as a shortage of cash but as a shortage of biomass resources to meet basic survival needs. Gross Nature Product is more relevant than the Gross National Product.

\section{REFERENCES}

Agarwal, Anil: Towards green villages. Gobar Times, Down to Earth Supplement, pp. 66-67, Centre for Science and Environment, New Delhi (15 July, 2004).

Annabel, Rodda: Women and the environment. United Nations - Non Governmental Liaison Services. pp. 47-49, Zed books Ltd., London (1991).

Columbia University, U S A: Rule out the Menace. Down to Earth, pp. 21, Centre for Science and Environment, ,New Delhi (15 June, 2002)

Columbia University, U S A: Pestilence at Birth. Down to Earth, pp. 21, Centre for Science and Environment, New Delhi (31 March, 2003)

Dankelman, Irene and Davidson, Joan: Women and Environment in the Third World: Alliance for the Future. pp. XI, 8-9,Earthscan Publications Ltd., London (2004)

Emroy University School of Medicine, U S A: Pesticide to Parkinson's, Down to Earth , pp 41, Centre for Science and Environment, New Delhi (31 December 2004)

Gobar Times Poster, Down to Earth, pp. 30, Centre for Science and Environment, New Delhi (15 July, 2004)

Kabra,S.G.: cited from Lal, G. Pranay and Bahl, Sarita: Soft Target. Down to Earth, pp. 27, Centre for Science and Environment, New Delhi (15 June, 2002)

Lal, G. Pranay and Bahl, Sarita: Soft Target. Down to Earth, pp. 26-27, Centre for Science and Environment, New Delhi (15 June, 2002)

Mies, Maria: Indian Women in Subsistence and Agricultural Labour. Vistar Publications, New Delhi (1987).

Mies, Maria and Shiva, Vandana: The Impoverishment of Environment: Women and Children Last, Ecofeminism. pp. 70-75 Kali for Women, New Delhi (1993).

Sachadev, Anupam and Dutta, A. K.: Tropic of Cancer. Down to Earth, pp. 30, Centre for Science and Environment, New Delhi (15 June, 2002) 
Sawai Man Singh Medical college, Group of Researchers: Pestering the Glands, Down to Earth, pp. 23, Centre for Science and Environment, New Delhi (30 November, 2002)

Swaminathan, M S: Poverty has a Woman's face. In Gobar Times, Down to Earth., Supplement, pp.6869 Centre for Science and Environment, New Delhi (15 th July 2004).

Shiva, Vandana: Staying Alive: Women Ecology and
Survival in India. pp. 96-98,114-116, Kali for Women, New Delhi (1992)

Tiwari, Rajinish: Milk Shake - Emissions of Illegal Land Fills Poison Breast Milk Down to Earth, pp. 22, Centre for Science and Environment, New Delhi (15 Jan, 2004)

WHO: Best Among the Worst. Down to Earth, p. 21 , Centre for Science and Environment, New Delhi (30 November, 2002) 